\title{
El cuestionamiento de lo racional en la prosa del fin de siècle desde una perspectiva hispanoamericana y centroeuropea ${ }^{1}$
}

\section{Dora Poláková}

Resumen. El artículo se centra en la ambigua postura que los artistas del fin de siècle adoptan ante la adoración del conocimiento racional. Muestra como los artistas destacan en sus obras otros niveles de la realidad; lo fantástico, lo misterioso, lo raro. Este punto de vista es común a los modernistas hispanos y a los autores checos aunque vivan y escriban en contextos históricos y sociales diferentes.

Palabras clave: modernismo; fin de siècle; prosa; fantástico; enigma; Darío; Karásek.

[en] The questioning of the rational in the prose of the fin de siècle from a Latin American and Central European perspective

\begin{abstract}
The article focuses on the ambiguous position that the artists of the fin de siècle adopt in the face of the worship of rational knowledge. It shows how artists highlight other levels of reality in their works; the fantastic, the mysterious, the weird. This view is common to Hispanic modernists and Czech authors even if they live and write in different historical and social contexts.
\end{abstract}

Keywords: modernism; fin de siècle; prose; fantastic; enigma; Darío; Karásek.

Sumario. 1. En busca de la modernidad. 2. Creación de nuevos mundos. 3. Tras lo oculto. 4. Zona de lo fantástico.

Cómo citar: Poláková, D. (2021) El cuestionamiento de lo racional en la prosa del fin de siècle desde una perspectiva hispanoamericana y centroeuropea, en Anales de Literatua Hispanoamericana 50, 83-94.

El progreso moderno es enemigo del ensueño y del misterio en cuanto se ha circunscrito a la idea de la utilidad. Mas, no habiéndose todavía dado un solo paso en lo que se refiere al origen de la vida y a nuestra desaparición en

la inevitable muerte, el ensueño y el misterio permanecen con su eterna atracción.

(Darío, “El pueblo del Polo", 1950-1053: 545)

La época de finales del s. XIX y principios del XX sigue fascinándonos -también nosotros hemos vivido relativamente hace poco un cambio de siglo y las preocupaciones que se asoman de los textos de aquel fin de siglo se parecen, quizá sorprendentemente, a los de este-. Y hay otro punto de interés: vemos como la época conocida en el ámbito hispano como modernismo muestra elementos comunes con las literaturas de otras

\footnotetext{
${ }^{1}$ El trabajo fue financiado por el Fondo Europeo de Desarrollo Regional-Proyecto "Creatividad y adaptabilidad como condiciones del éxito de Europa en un mundo interrelacionado" (reg. no.: CZ.02.1.01/0.0/0.0/16_019/0000734).

${ }^{2}$ Univerzita Karlova. Chequia.

Email: dora.polakova@,ff.cuni.cz
} 
lenguas, regiones o culturas. Los contextos regionales pueden ser diferentes, no obstante, los problemas y los puntos de vista con los que los intelectuales y artistas los miran muestran varias simlitudes. ${ }^{3}$

En este artículo me gustaría esbozar un tema clave del periodo finisecular: la relación problemática con la ciencia y el racionalismo y la búsqueda del sentido del mundo en lo mágico, sobrenatural y extraño. De ejemplo nos van a servir los cuentos de Rubén Darío (1867-1916) y las novelas cortas del escritor checo Jiř́i Karásek ze Lvovic ${ }^{4}(1871-1951)$.

\section{En busca de la modernidad}

Como es bien sabido, el modernismo hipanoamericano está lleno de paradojas y ambigüedades. Es, a la vez, parte de una amplia corriente espiritual -en la famosa cita Federico de Onís habla del modernismo como de la "forma hispánica de la crisis universal de las letras y del espíritu" (Onís, 1961: XV)- y un movimiento original hispanoamericano. Significó tomar cierta postura ante los cambios bruscos que la humanidad estaba viviendo, fue una reacción ante la crisis de valores que la civilización occidental estaba enfrentando. Es decir, se trataba nada menos que de la manera en que la sociedad iba a entrar en una nueva época, en la modernidad.

El modernismo representa así el momento cuando la región hispanoamericana reclama con creciente orgullo su lugar en la escena mundial: lo hace reconociendo su individualidad, así como su pertenencia a una tradición común.

Hispanoamérica absorbe impulsos provenientes sobre todo de Europa, sigue atentamente el auge de las ciencias naturales, nuevas ideas filosóficas, así como manifestaciones de fatiga y decadencia que el "Viejo mundo" vive a finales de siglo. Y siente como ella también entra en la modernidad. Pero el camino hacia el mundo moderno es complicado. Como apunta Aníbal González, en el s. XIX la modernidad de Hispanoamérica es aún problemática, "el espíritu moderno de la incipiente burguesía hispanoamericana deberá enfrentarse a una realidad arcaica y amenazante" (González, 1983: 5) y se pregunta, hasta qué punto es realizable. Las emblemáticas obras literarias del periodo, consideradas románticas, juegan un papel clave en la formulación de dicha pregunta; textos como El matadero de Echeverría, Facundo de Sarmiento o Amalia de Mármol representan "en mayor o menor grado, alegatos, propuestas o programas para el establecimiento de la modernidad en Hispanoamérica" (González, 1983: 7). Y justo el modernismo significa la culminación del pensamiento hispanoamericano del s. XIX. Toma una postura radicalmente diferente, cambia el punto de vista y el tono en el cual transcurre el debate. "En vez de señalar la necesidad de ser modernos, los escritores modernistas hacen su literatura desde el supuesto de que ya son modernos," resume Aníbal González (1983: 7). No obstante, ¿qué significa ser moderno?:

Ser moderno significaba, en reglas generales, un medio ambiente novedoso: ferrocarriles, máquinas de vapor, fábricas, telégrafos, periódicos, diarios, teléfonos, descubrimientos científicos, centros urbanos que cambiaban la conformación de la sociedad y la distribución de las tradicionales clases sociales. Ser moderno -en términos occidentales- era también el optimismo tecnológico donde el hombre, como diseňador, mejoraría el mundo material; la sociedad podría alcanzar la mejor de las utopías gracias a los ideales de la eficiencia. (Roetker, 2005: 31)

Los artistas entienden este concepto general de la modernidad como problemático y se oponen con vehemencia a algunos de sus rasgos, pero siempre considerándose modernos. Los términos moderno, modernidad... encierran en sí una ambigüedad de significado y de valores. Y así es la relación de los modernistas con lo moderno. Son representantes de la modernidad, aprovechan sus adelantos y posibilidades, siendo simultáneamente sus críticos agudos.

¿No encarna, acaso, esta ambigüedad uno de los rasgos constitutivos de la modernidad?

\footnotetext{
${ }^{3}$ En la Facultad de Letras de la Universidad Carolina de Praga hemos dedicado a esta cuestión varios simposios y publicaciones, véase por ejemplo el libro Dusk and Dawn. Literature Between Two Centuries. Eva Voldřichová Beránková y Šárka Grauová (eds.). Praha: Univerzita Karlova, Filozofická fakulta, 2017.

${ }^{4}$ Poeta, prosista, traductor, crítico (no solo de la literatura, sino también de las artes plásticas), figura insigne del decadentismo checo. Añadió a su apellido el atributo "ze Lvovic" (de Lvovice) para darse la apariencia de un descendiente de la nobleza, subrayando así su desdeño de lo vulgar y cotidiano.
} 
De manera parecida $-\mathrm{y}$ a la vez distinta- viven estas paradojas finiseculares los artistas checos. A diferencia de los hispanoamericanos, aún no gozan de identidad nacional y estatal plena. Los países checos (que incluyen Bohemia, Moravia y Silesia) siguen formando parte del Imperio austro-húngaro que paulatinamente va modernizándose en algunos aspectos económicos, políticos y sociales, pero que no admite la existencia "política" de sus distintas naciones eslavas y, por consiguiente, no les otorga autonomía. En consecuencia, desde el S. XVIII somos testigos de un fuerte "renacimiento nacional" (que coincide con el romanticismo) en cuyo marco las élites reclaman derechos políticos y tratan de construir y ofrecer al público cierto arte "nacional". Un elemento clave de este movimiento lo constituye la labor por avivar la lengua checa y dotarla del léxico necesario para el mundo actual; es decir, la lucha por la identidad es también una lucha lingüística. De allí que el arte sea considerado un instrumento o incluso arma en dicho combate.

Como apunta el crítico Otto Urban, "la sociedad checa constituye a finales del s. XIX un elemento evidente de la comunidad cultural europea. No obstante, no forma parte de la comunidad política y su autonomía política también le es negada dentro del estado en el cual vive. [...] La cuestión checa es así no solo objeto de discusiones y peleas teóricas, sino un problema práctico vivido por una generación que en la excitación de los años noventa busca su sitio en la sociedad" (Urban, 1995: 33).

En esta atmosféra de luchas y búsquedas se forma el movimiento de la moderna checa, que -igual que el modernismo- quiere hacer un arte libre y desde la modernidad. Un arte sin normas, que constituya "un área autónoma de la actividad humana y como tal tenga valor por sí mismo. Solo como una expresión totalmente libre el arte puede integrarse en la sociedad y ser aceptado o rechazado por ella" (Urban, 1995: 35).

Igual que los hispanoamericanos, los artistas checos viajan por el mundo y su destino principal no podría ser otro que París (allí trabaja, por ejemplo, el pintor mundialmente conocido Alfons Mucha). Su horizonte se amplía. "El arte europeo del momento actual se hace internacional, se deshace de los grillos de las fronteras y normas," pregona el crítico y escritor decadente Arnošt Procházka (1896: 69). Los artistas son cosmopolitas y absorben la atmósfera bohemia, decadente y simbolista. Y tienen que hallar cierto equilibrio entre el compromiso nacional y el arte que encuentra su razón de ser en sí mismo. Este movimiento entre dos polos divergentes se muestra, a menudo, muy problemático y los escritores "cosmopolitas" son objeto de crítica por su presunta huida ante los problemas de la nación. ¡Qué parecido con la etiqueta de escapistas y esteticistas que se les solía dar a los modernistas! No obstante, desde la pespectiva posterior ambas vertientes se muestran fructíferas y los escritores decadentes y simbolistas de la moderna juegan en la literatura checa un papel crucial en la apertura de horizontes artísticos y la entrada en la modernidad -igual que en el ámbito hispano- justo por su acento en la autonomía del arte y la importancia de los mundos ficticios creados por el artista. ${ }^{5}$ Arnošt Procházka, uno de los representantes del decadentismo checo, afirma: "El arte no existe para reflejar la vida, para reproducirla, para servirla. El arte existe por sí solo, para crear de todo nuevos valores sui generis, nuevos mundos fuera del mundo dado..." (Procházka. 1913: 81).

\section{Creación de nuevos mundos}

Esta búsqueda y creación de nuevos mundos se hace agudamente necesaria, ya que el final del s. XIX trae sentimientos de crisis, decadencia, vacío... siendo a la vez un momento en el cual hierven nuevas ideas, ideologías, nuevas miradas hacia el arte y el mundo en general:

El modernismo es un movimiento nacido de una crisis; es la respuesta hispanoamericana a la fragmentación y enajenación generadas por la sociedad moderna; su objetivo final es recobrar, por medio del arte, una sensación de de pertenencia e integración. (Jrade, 1986: 38)

Ya en 1882 José Martí ofrece una diagnosis bien conocida y extremadamente clarividente de la época:

Nadie tiene hoy su fe segura. Los mismos que lo creen, se engañan. Los mismos que escriben fe se muerden, acosados de hermosas fieras interiores, los puños con que escriben. [...] No hay obra permanente, porque las

\footnotetext{
${ }^{5}$ Esta postura ante el arte la refleja la revista Moderní revue, publicada de 1894 a 1925 y cuyas figuras claves fueron Arnošt Procházka y Jiří Karásek, ambos mencionados en este artículo. La revista acentuó el aspecto formal colaborando con pintores simbolistas. Mantenía, a veces, posturas que resultaban escandalosas para gran parte de la población; así, por ejemplo en 1895, después de que Oscar Wilde fuera condenado por el tribunal, publicó un número dedicado al escritor, defendiendo, además, la homosexualidad. Este y otros números fueron confiscados por atentar contra la moral.
} 
obras de los tiempos de reenquiciamiento y remolde son por esencia mudables e inquietas; no hay caminos constantes, vislúmbranse apenas los altares nuevos, grandes y abiertos como bosques [...] Todo es expansión, comunicación, florescencia, contagio, esparcimiento. (Martí ,2013: 19-24)

Martí de forma sugerente y poética expresa la inseguridad del hombre moderno. De cara al tiempo precipitado en un mundo que cambia vertiginosamente, se siente solo, desarraigado. Ninguna fe, ninguna creencia parece constante, incluso la palabra carece de valor duradero. La fe ciega en el conocimiento racional es considerada por Martí como peligrosa - puede llevar a una falta de humildad, a la incapacidad de escuchar a los demás y sobre todo a lo que trasciende al hombre (recordemos su verso famoso: "el universo habla mejor que el hombre" del poema "Dos patrias").

De modo parecido habla en 1896 Arnošt Procházka:

Los fines de los siglos se parecen: son siempre turbios e inestables. Estas palabras ya las conocemos, igual que la afirmación de que nos encontramos en una época de transición. [...] Enterramos viejas opiniones en la tumba, llenamos con ellas museos y colecciones de antigüedades, entramos en una nueva época de desarrollo, en el imperio de nuevos valores y estados. Los frutos maduros se caen de los árboles, sin que lo nuevo y futuro aún tenga una forma definida y completa. De allí la vacilación, la inseguridad. Se está produciendo una gran mudanza de espíritu. (Urban 1995: 24)

El cambio del espíritu está íntimamente ligado a la búsqueda del papel del hombre en el mundo; el papel de su razón. La razón humana que parece que no tiene límites y que puede encontrar respuestas a todo. Justo el final del s. XIX está vinculado con el auge de las ciencias naturales y del positivismo. Eso conlleva por un lado un progreso incuestionable en la técnica y la ciencia (por ejemplo en la medicina), por otra parte desemboca en cierta arrogancia de la especie humana, en una adoración ciega de la razón. Se debilitan las religiones tradicionales, la fe ancestral está puesta en duda. No obstante, la razón no es capaz de llenar el vacío surgido:

Al hombre moderno no le satisface lo que le ofrecen la cienca y la vida cotidiana. [...] Está cansado y desdichado, anhela algo tranquilo, sereno, sagrado, algo que le conquiste por su grandeza, profundidad y verdad, algo donde repose su cabeza febril; pero delante de sus coetáneos se avergüenza, quiere seguir jugando el triste papel del "superhombre" omnipotente -pero el público es igualmente, si no más, atormentado, triste y apenado como el propio actor. (Dražd’ák, 1995, 295)

\section{Tras lo oculto}

¿Cómo llenar ese vacío? Buscando en círculos ocultistas, libros esotéricos, logias masónicas... O volviendo al catolicismo tradicional, pero dotándolo frecuentemente de cierta forma estetizante: deleitándose con sus rituales, la opulencia barroca o el sacrificio de sus mártires - de esta forme agita la desgastada sensibilidad finisecular y apunta hacia momentos que ponen en duda lo científico y racional-. El bohemio/dandy encuentra parecidos entre su sufrimiento y marginalización (su arte no es comprendido por el vulgo y hasta es burlado) y el destino de profetas o santos - cuya fe y estilo de vida tampoco fueron aceptados. Es obvio como los viajes de artistas finiseculares y su búsqueda del sentido de la vida y del arte se asemejan a las peregrinaciones religiosas (y las retiradas del mundo de los ermitaños); de ejemplo sírvanos la novela inconclusa de Rubén Darío El oro de Mallorca, donde el protagonista (un claro alter-ego dariano), el músico Benjamín Itaspes, recorre Mallorca tras las huellas de Chopin y G. Sand, por un lado, y de Ramon Llull por el otro. El autor checo Jiř́ Karásek ze Lvovic le dedica a Ramon Lull un librito ${ }^{6}$ y asimismo lo menciona en la novela Román Manfreda Macmillena (La novela de Manfred Macmillen) de la que hablaré más adelante: "Es necesario infringir el orden y consentimiento del mundo - ser demonio en este sentido de Raymundo Lull." (Karásek, 2012: 135). Karásek, además, también escribe una novela claramente autobigráfica El paraíso perdido (como folletín 1933-34, en forma de libro 1938), en clara alusión a la epopeya de John 
Milton (1667). Su protagonista, el andrógino Viktor Šonský, expresa su otredad y marginalización, esa búsqueda vana de un paraíso, su isla de oro.

Los artistas finiseculares -y sus héroes- se sienten otros y au anhelo de armonía se ve continuamente frustrado (la abundancia de textos sobre el artista y su relación con la sociedad es, por consiguiente, lógica).

No obstante, el problema no es únicamente llegar a un entendimiento de sí mismo, encontrar un sitio digno en el mundo. La existencia humana como tal se muestra ilógica, absurda...sin sentido. ¿Cómo entonces vivirla?

La vida entera se convierte en un viaje de iniciación, en el cual se busca la manera de comprender el mundo (si la razón es insuficiente). Así, paradójicamente, la edad de la razón es, a la vez, una edad hechizada por la sinrazón, por lo irracional, por lo que se escapa de las coordenadas de lo racional, lo que no sabemos nombrar y mucho menos explicar. Esta tensión moderna se manifiesta claramente en la literatura:

Su acción [del positivismo] fue semejante a la de la Ilustración en el siglo XVIII; las clases intelectuales de América Latina vivieron una crisis en cierto modo análoga a la que había atormentado un siglo antes a los europeos: la fe en la ciencia se mezclaba a la nostalgia por las antiguas certezas religiosas, la creencia en el progreso al vértigo ante la nada. No era la plena modernidad, sino su amargo avant-goût: la visión del cielo deshabitado, el horror ante la contingencia. (Paz, 1999: 497)

La respuesta artística a esa mezcla de fe en el progreso moderno y el horror ante lo mismo lo representa justo el modernismo y su versión centroeuropea. Así podemos comprender la esencia ambigua del arte finisecular: lucha con los sentimientos contradictorios del fin de siglo y rechaza la simplificación del mundo y del universo en un proyecto racionalmente explicable:

Unos cuantos, Darío el primero, advierten que la modernidad no es sino un girar en el vacío, una máscara con la que la conciencia desesperada simultáneamente se calma y se exaspera. Esa búsqueda, si es búsqueda de algo y no mera disipación, es nostalgia de un origen. El hombre se persigue a sí mismo al correr tras este o aquel fantasma: anda en busca de su principio. (Paz, 1969: 23)

En la prosa finisecular vemos el dilema de la modernidad tratado con gran urgencia. Los géneros prosaicos (cuento, novela) se muestran sumamente apropiados para dar cabida a las preocupaciones más personales -pero a la vez más universales- de los escritores de la época. ${ }^{7}$

\section{Zona de lo fantástico}

Lo que nos interesa en este momento es, sobre todo, la variante fantástica del cuento que "es también con frecuencia (las grandes obras lo prueban) el medio de ahondar en los grandes problemas del hombre: metafísicos, teológicos, morales, estéticos..." (Carilla, 1968: 6). Por supuesto, no es un invento modernista; hay una tradición romántica en el suelo hispanoamericano y sobre todo una nómina de grandes maestros europeos y estadounidenses, sobre todo E. A. Poe. ${ }^{8}$ Personaje clave para Darío, Quiroga, Lugones y muchos otros... Darío subraya esa "rareza" del maestro estadounidense (y lo incluye, naturalmente, entre Los raros): "Poe, como un Ariel hecho hombre, diríase que ha pasado su vida bajo el flotante influjo de un extraño misterio. Nacido en un país de vida práctica y material, la influencia del medio obra en él al contrario. De un país de cálculo brota imaginación tan estupenda" (Darío, 1920: 22).

\footnotetext{
7 "El modernismo inicia en Hispanoamérica la concepción y la praxis moderna del cuento como un artefacto de precisión semejante al poema lírico por el relieve que cobran en él la apretada unidad, la síntesis, el valor de los detalles y la carga expresiva de las palabras. [...] Por su brevedad y por el reto que representa en términos artísticos, llamó poderosamente la atención y se ajustó perfectamente a la mentalidad y la estética modernistas" (Acevedo, 2002: 102). Asimismo recordemos como la novela modernista se centra en la historia personal del protagonista, muchas veces narrador, sus anhelos amorosos y artísticos (véase, por ejemplo, el libro de Aníbal González La novela modernista hispanoamericana).

8 "Lo que está muy claro es que la literatura fantástica del modernismo hispanoamericano no heredó del gran sevillano [Bécquer], sino de Poe, Hoffmann, y por vía muy directa, de Holmberg, una tendencia que llamaremos cientifista”, apunta Luis Sáinz de Medrano (1991: 18).
} 
Para los modernistas el cuento fantástico es un género perfecto para expresar su postura ambigua ante el progreso, la técnica, las ciencias, las religiones etc. ${ }^{9}$ Asimismo refleja su inseguridad en la comprensión del mundo y de sí mísmos; recordemos las pesadillas de Darío o su miedo extremo ante la muerte. ${ }^{10}$

David Roas, teórico de la literatura fantástica, subraya que:

el relato fantástico provoca $-\mathrm{y}$, por tanto, refleja- la incertidumbre en la percepción de la realidad y del propio yo. [...] La literatura fantástica nos descubre la falta de validez absoluta de lo racional y la posibilidad de la existencia, bajo esa realidad estable y delimitada por la razón en la que habitamos, de una realidad diferente e incomprensible, y, por lo tanto, ajena a esa lógica racional que garantiza nuestra seguridad y nuestra tranquilidad. En definitiva, la literatura fantástica pone de manifiesto la relativa validez del conocimiento racional al iluminar una zona de lo humano donde la razón humana está condenada a fracasar. (Roas 2001: 9)

Los modernistas buscan maneras como introducir elementos fantásticos en el texto. Se basan en los procedimientos románticos pero pretenden debilitar lo terrorífico explícito del espacio y de los personajes (ya no habrá tantas ruinas de castillos, noches tormentosas, muertos que se levantan de la tumba etc.) para poder llegar a un fantástico más refinado, unido estrechamente con los rasgos del mundo moderno y el progreso científico que les rodea. (Por supuesto no podemos todavía hablar de lo fantástico de lo cotidiano, pero ya se vislumbra un camino hacia ello).

Lo fantástico aparece como algo que horroriza por su carácter indescifrable, inasible -"el mundo fantástico puede ser todo, menos consolador" afirma Rosalba Campra (2001: 160)-como algo inexplicable. Nos llena de inquietud, nos hace preguntarnos por la esencia del mundo que captamos con nuestros sentidos...

El cuento fantástico suele tener un final abierto u ofrece dos o más soluciones; el lector puede, pero no tiene que, elegir una de ellas. Los cuentistas del modernismo refuerzan la credibilidad y verosimilitud de lo narrado; ponen fechas exactas, describen con detalle el espacio, indican el origen oral del texto llevando al lector a la esfera de las vivencias del narrador. Este constituye el elemento clave de las narraciones fantásticas; suele aparecer como testigo o protagonista. En ambos casos cuenta en primera persona, lo que reduce la distancia entre la narración y el lector, pero a la vez quita seguridad (el narrador puede soñar, puede tener problemas psíquicos, puede estar borracho o drogado): "La primera persona siempre es sospechosa, porque nada, a excepción de ella misma, garantiza lo narrado. ¿Cómo saber si el suyo es un testimonio desinteresado? [...] La primera pesona protagonista tiene el don fatídico de contaminar de duda la existencia misma del acontecimiento" (Campra, 2001: 170).

Además de estos rasgos generales me gustaría mencionar dos aspectos que considero esenciales: el tema de Hispanoamérica como espacio donde lo fantástico se muestra inherente a la realidad, y la relación de lo fantástico con la ciencia. Ambos momentos los podemos rastrear en la cuentística de Rubén Darío y veremos como se dan de forma paralela en el caso checo.

El autor nicaragüense se dedica al género fantástico sobre todo entre los años 1893-1914, es decir, que su aparición está estrechamente relacionada con la estancia de Darío en Buenos Aires (1893-98). La metrópoli argentina le proporcionó una atmosféra cosmopolita que contribuyó a los frutos magistrales de ese periodo (Los Raros y Prosas profanas, 1896) y también a las excursiones al terreno fantástico, impulsadas, sin duda, por la gran tradición de literatura fantástica en la región rioplatense. ${ }^{11}$

Pero volvamos a las cuestiones que nos interesan en los textos darianos.

Mientras que la literatura fantástica del romanticismo en Hispanoamérica suele ubicar las historias en espacios lejanos (muchas veces europeos) o en lugares no definidos, en el modernismo el espacio hispanoamericano va adquiriendo una importancia vital y suele ser presentado como un ambiente natural para fenómenos sobrenaturales. Así dice el protagonista del cuento "La larva" de Rubén Darío:

\footnotetext{
9 “La novedad en nuestros narradores fantásticos de fin de siglo parece estar en esta 'increíble' convivencia de ciencia y religión, de racionalidad y teosofía y espiritualismo, de herencia romántica remozada frente al esplendor científico que se despliega y se presiente para un futuro muy próximo" (Morillas Ventura, 1999: 274).

${ }^{10}$ Dice en Historia de mis libros: “ ¡Ay! Nada ha amargado más las horas de meditación de mi vida que la certeza tenebrosa del fin. ¡Y cuántas veces me he refugiado en algún paraíso artificial, poseído del horror fatídico de la muerte!” (Cf. Acereda, 1992: 70).

${ }^{11}$ Recordemos a los escritores románticos, mencionados más arriba, y los que siguen en esta dirección durante todo el siglo XX: Lugones, Quiroga, Felisberto Hernández, Borges, S. Ocampo, Bioy Casares, Cortázar.
} 
Yo nací en un país en donde, como en casi toda América, se practicaba la hechicería y los brujos se comunicaban con lo invisible. Lo misterioso autóctono no desapareció con la llegada de los conquistadores. Antes bien, en la colonia aumentó, con el catolicismo, el uso de evocar las fuerzas extrañas, el demonismo, el mal de ojo. En la ciudad en que pasé mis primeros años se hablaba, lo recuerdo bien, como de cosa usual, de apariciones diabólicas, de fantasmas y de duendes. (Darío, 2011: 302)

Y, en efecto, lo misterioso autóctono ocupa el escenario: somos testigos de una historia fantástica ubicada en una ciudad latinoamericana, descrita de forma realista, contrastando su "normalidad" con lo "anormal" que viene a continuación: el protagonista adolescente desea conocer los secretos de la vida nocturna, sobre todo los encantos de las mujeres, y durante su paseo secreto por las calles se encuentra con una figura femenina; cual es su asombro y horror, cuando ve la cara descompuesta, espeluzante de una "larva", es decir, de una criatura muerta, que se mueve entre el mundo de los vivos y el más allá: “...aquella figura se volvió hacia mí, descubrió su cara, y ¡oh, espanto de los espantos! Aquella cara estaba viscosa y deshecha; un ojo colgaba sobre la mejilla huesosa y saniosa; llego a mí como un relente de putrefacción.” (Darío, 2011: 304)

La estructura de la narración es asimismo sintomática del cuento fantástico de la época: Darío presenta un marco contado por un narrador sin nombre, en el cual está metida la propia historia fantástica protagonizada y narrada por Isaac Codomano, amigo de ese narrador anónimo. Así tenemos en realidad dos narradores en primera persona, uno quien ha vivido los acontecimientos sobrenaturales en sus propias carnes, el otro que oye la historia y la reproduce. Isaac en dos momentos subraya la verosimilutud de lo narrado: "Yo os juro que he visto, como os estoy viendo a vosostros, si no una salamandra, una larva o una empusa." (Darío, 2011: 302), "Os doy mi palabra de honor, concluyó Isaac Codomano, que lo que os he contado es completamente cierto." (Darío, 2011: 304). No obstante, la duda se mantiene: ¿es un recuerdo verdadero? ¿No puede estar modificado por la memoria, por la distancia temporal (Isaac fue un adolescente cuando ocurrió)? ¿Y no pudo ser, acaso, una alucinación, un sueño? El cuento no nos expĺica cómo pudo suceder; sólo pone este intersticio de sinrazón ${ }^{12}$ ante nuestros ojos.

Algo semejante ocurre en el relato "Huitzilopochtli"13 (1914), considerado el último cuento del autor. Ya el subtítulo leyenda mexicana nos advierte que nos moveremos en el terreno de los mitos ancestrales. Lo interesante es que el pasado precolombino se combina en este caso con la actualidad que vive el autor: la revolución mexicana. El narrador es un periodista que emprende un viaje hacia las tropas revolucionarias en compañía del también periodista y médico John Perhaps (el significado de su apellido, quizá, no es casual) y del padre Reguera, "uno de los hombres más raros y terribles que haya conocido en mi vida" (Darío 2011: 340). Atraviesan la naturaleza salvaje, se encuentran con indios y el americano súbitamente desaparace. El narrador lo busca en la selva y ve un altar precolombino y alrededor de él un ritual mágico: los indios les ofrecen a los dioses una ofrenda -el sacrificado no es otro que Mr. Perhaps-.

Esta historia sencilla ofrece varios momentos interesantes: no sabemos, cuál es la verdad, ni lo sabe el narrador, ya que duda de lo visto en la selva. La imagen presenciada tiene rasgos sobrenaturales; como si el testigo se desplazara a otro tiempo. Por el altar se deslizan serpientes y la escena es seguida por un grupo de coyotes; no obstante, los indios que ejecutan el sacrificio parecen "civilizados" -son los que acompañan a los viajeros-. Además, el narrador presencia la escena después de haber fumado tabaco con marihuana (ofrecido por el padre Reguera), asi que su percepción está modificada. Reguera es el personaje más ambiguo y enigmático: soldado y cura, revolucionario y a la vez un hombre convencido de la necesidad de la presencia divina en la figura del gobernador. Cristiano que le trata de convencer al narrador sobre el poder de las divinidades aztecas... El cuento termina con una alusión misteriosa:

Pregunté por el padre Reguera. -El coronel Reguera -me dijo la persona que estaba cerca de mí- está en este momento ocupado. Le faltan tres pos fusilar.

Vino a mi cerebro, como escrito en letras de sangre: Huitzilopoxtli. (Darío, 2011: 344)

El padre Reguera nos es presentado, entonces, como alguien ligado a la muerte y lo sobrenatural: él ofrece la droga seguida de una visión (¿o realidad?) horrorífica, él ejecuta, él esconde bajo una capa cristiana

\footnotetext{
${ }^{12}$ El término lo usa J. L. Borges en "Avatares de la toruga", donde afirma: "Nosotros hemos soñado el mundo. Lo hemos soñado resistente, misterioso, visible, ubicuo en el espacio y firme en el tiempo; pero hemos consentido en su arquitectura tenues y eternos intersticios de sinrazón para saber que es falso" (Borges, 1976: 116).

${ }^{13}$ El dios azteca Huitzilopochtli se relaciona con el Sol y la guerra. Se le ofrecían sacrificios humanos.
} 
hondos conocimientos de las creencias indígenas de cuyo poder y presencia está convencido ("Te advierto una cosa: con la cruz hemos hecho aquí muy poco; y por dentro y por fuera, el alma y las formas de los primitivos ídolos nos vencen.” Darío, 2011: 342). ¿Tiene algo que ver con la desaparición de Mr. Perhaps? Creyendo o no su sacrificio ritual, lo cierto es que desaparece y el texto no ofrece otra explicación. Todo en el cuento es borroso, todo es quizá - igual que su nombre: la identidad de los personajes, sus hechos, sus pensamientos. Lo fantástico está presentado como una parte inherente de la realidad mexicana:

Aquí en México, sobre todo, se vive en un suelo que está repleto de misterio. Todos esos indios que hay no respiran otra cosa. Y el destino de la nación mexicana está todavía en poder de las primitivas divinidades de los aborígenes. En otras partes se dice: "Rascad... y aparecerá el...".

Aquí no hay que rascar nada. El misterio azteca, o maya, vive en todo mexicano por mucha mezcla social que haya en su sangre, y esto en pocos. (Darío, 2011: 340)

Lo "misterioso autóctono" dariano subraya que los europeos no han descubierto un continente vacío, que la tradición traída por el mar no ha anulado del todo la herencia original, qur el mundo moderno, racional no ha abolido el subsuelo mítico.

La segunda piedra angular de lo fantástico dariano -y modernista, en general- es su vinculación con la ciencia. Ya hemos dicho que esta relación no es sólo uno de los ejes de la estética modernista, sino también de las luchas y vacilaciones vitales de los autores. El cuento fantástico problematiza la actitud racional y científica ante el mundo. Ambos mundos -el racional, analítico y el misterioso, imaginativo- deberían complementarse, pero la realidad les muestra más bien como rivales. La admiración modernista hacia la ciencia viene acompañada de su crítica y de una advertencia constante: en el conocimiento humano quedan lagunas extensas de ignoracia y misterio.

Así es la opinón del doctor, Z, protagonista del cuento "El caso de la señorita Amelia"14 de Rubén Darío:

¿Quién es el sabio que se atreve a decir esto es así? Nada se sabe. Ignoramus et ignorabimus. ¿Quién conoce a punto fijo la noción del tiempo? Quién sabe con seguridad lo que es el espacio? Va la ciencia a tanteo, caminando como una ciega, y juzga a veces que ha vencido cuando logra advertir un vago reflejo de la luz verdadera. [...] Nada ha logrado saberse con absoluta seguridad en las tres grandes expresiones de la Naturaleza: hechos, leyes, principios. Yo que he intentado profundizar en el inmenso campo del misterio, he perdido casi todas mis ilusiones. Yo que he sido llamado sabio en las Academias ilustres y libros voluminosos; yo que he consagrado toda mi vida al estudio de la humanidad, sus orígenes y sus fines; yo que he pentrado en la Cábala, en el ocultismo y en la teosofía, que he pasado del plano material del sabio al plano astral del mágico y al plano espiritual del mago [...] yo que ahondé en el Karma búdhico y en el misticismo cristiano, y sé al mismo tiempo la ciencia desconocida de los fakires y la teología de los sacerdotes romanos, yo os digo que no hemos visto los sabios ni un solo rayo de la luz suprema, y que la inmensidad y la eternidad del misterio forman la única y pavorosa verdad. (Darío, 2011: 225-226)

Opino que este fragmento expresa perfectamente la relación de los modernistas no sólo con la ciencia, sino con el conocimiento en general, ya que el camino del conocimiento está vinculado tanto con la ciencia como con la religión. El doctor $\mathrm{Z}$ es la síntesis de la escisión finisecular e ilustra el anhelo de la sabiduría y simultáneamente la conciencia de los límites de la misma. Oscar Hahn, además, muestra que comparte rasgos con un personaje real, madame Blavatsky ${ }^{15}$, cuyos escritos teosóficos los modernistas hispanoamericanos solían leer. El discurso que pronuncia el doctor antes sus amigos antes de contar la propia historia fantástica ${ }^{16}$ es por una parte una jactancia de un hombre que presume de todo lo que conoce, todo lo que ha estudiado y visto, y por eso se merece el título de sabio, por otra parte es una confesión de debilidad. Aunque haya tratado de penetrar en cualquier creencia, religion, filosofía, aunque haya buscado en

\footnotetext{
${ }^{14}$ Oscar Hahn considera que el tratamiento del tiempo en este cuento se parece al tiempo borgiano. "Su viaje [del doctor Z] es el equivalente lineal de lo que Borges concentrará después en el Aleph" (Hahn, 1982: 76).

15 “Como ella, el doctor $Z$ va a la India con el fin de estudiar y difundir la teosofía y el gnosticismo; como ella, dedica alrededor de veinte años a viajar por el mundo; y como ella, pasa una temporada en el Tíbet bajo el magisterio de los mahatmas. Otra coincidencia curiosa es que el doctor $\mathrm{Z}$ dice haber ayudado al coronel Olcot [sic] a fundar la rama teosófica de New York, y en la realidad Madame Blavatsky ayudó al coronel Henry Steel Olcott, en 1875, en la fundación de la Sociedad Teosófica de New York." (Hahn, 1982: 77)

${ }^{16}$ En ella se nos cuenta la historia de Amelia Revall; el doctor la conoce como una niña de trece años y cuando vuelve después de 23 años de sus viajes por el mundo, tiene el mismo aspecto de una adolescente: "Se ha detenido para ella el reloj del tiempo, en una hora señalada, ¡quién sabe con qué designio del desconocido Dios!" (Darío, 2011: 229)
} 
el pasado o siga doctrinas modernas, el resultado ha sido siempre el mismo: la esencia del mundo y del universo queda escondida. El enigma triunfa. El anhelo (vano) del conocimiento está presente también en la cuento "La extraña muerte de fray Pedro" (1913). En un convento el narrador dialoga con un monje que le cuenta la historia del fray Pedro, quien se dejó tentar por "el demonio moderno que se escuda con la Ciencia" (Darío, 2011: 330). Su curiosidad, su deseo de comprenderlo todo, le iba alejando de la verdadera fe y lo llevaba hacia las ciencias ocultas, pero tambén hacia los últimos inventos científicos. Así está convencido de que los rayos $\mathrm{X}$ podrían probar la existencia divina:

¡Si en Lourdes hubiese habido un Kodax, durante el tiempo de las visiones de Bernardetta! ¡Si en los momentos en que Jesús, o su Santa Madre, favorecen con su presencia corporal a señalados fieles, se aplicase convenientemente la cámara oscura!... ¡Oh, cómo se convencerían los impíos, cómo triunfaría la religión! (Darío, 2011: 333)

Un día, cierto monje (pero con pezuñas de cabra debajo de la sotana) le trae el aparato deseado y fray Pedro se sumerge en sus experimentos. Al día sigueinte es encontrado muerto y un arzobispo y el padre provincial discuten sobre su vida y muerte:

-Ilustrísimo señor -decía éste-, a fray Pedro lo hemos encontrado muerto. No andaba muy bien de la cabeza. Esos sus estudios creo que la causaron daño.

- ¿Ha visto su reverencia esto? - dijo su señoría ilustrísima, mostrándole una revelada placa fotográfica que recogió del suelo, y en la cual se hallaba, con los brazos desclavados y una dulce mirada en los divinos ojos, la imagen de Nuestro Señor Jesucristo. (Darío, 2011: 334)

La narración termina e igual que en casi todos los demás cuentos fantásticos de Darío el lector se queda sin explicación alguna. El cuento refleja la compleja relación no sólo de la ciencia y lo fantástico, sino también de la ciencia y la religión. Ambas constituyen maneras del conocimiento y el hombre moderno está obsesionado por conocer, quiere domar el universo mediante sus conocimientos, pero éste se rebela. Podemos preguntarnos: ¿la fe necesita pruebas científicas? ¿No se trata de dos niveles diferentes de existencia humana? Si existiera una imagen de Jesús tomada con los rayos X, ¿qué sucedería? El anhelo de fray Pedro se muestra insano y fatal y lo podemos leer como una versión del mito de Fausto: la obsesión por conocer le puede llevar al hombre al infierno.

En el centro de Praga está la casa de Fausto, un edificio antiguo, donde -solamente en leyendas- Fausto vivió. Aunque no sea verdad, sí que fue una casa habitada en el pasado por alquimistas ${ }^{17}$, magos etc., una casa que encarna la Praga misteriosa y mágica. ${ }^{18}$ Esta atmosféra la aprovecharon los artistas finiseculares para situar en la ciudad historias que cuestionaban la omnipotencia y clarividencia de la ciencia subrayando niveles sobrenaturales y maravillosos del mundo -así Praga también goza de lo misterioso autóctono-.

Jan Neruda (1834-1891), Jakub Arbes (1840-1914), Gustav Meyrink (1868-1932) o Jiř́ Karásek ze Lvovic son solo algunos nombres de autores que ubican sus novelas y cuentos en el espacio praguense. Lo que les interesa de la ciudad es su alma, algo difícilmente definible, algo que hace del espacio casi un personaje. En las calles ocurre el nomadeo urbano (recordemos qué importancia adquiere la ciudad en el modernismo hispano), los personajes vagan por la ciudad buscándose a sí mismos, tratando de comprender su lugar en el mundo. Y Praga concebida como laberinto (con sus callejuelas medievales, el antiguo ghetto judío, los cementerios etc.) es un sitio idóneo para este viaje trascendental; el espacio refleja la inseguridad del protagonista, es testigo de sus ilusiones perdidas. Y, por supuesto, también se relaciona con los altibajos de la identidad checa.

Antes de fijarnos en algunos momentos de la obra de Jiří Karásek, detengámonos un rato en la famosa novela de Gustav Meyrink Golem ${ }^{19}$ (publicada en alemán en 1915, dos años más tarde en traducción checa). En ella vemos como el fin de siècle modifica las viejas leyendas acomodándolas a las preocupaciones finiseculares, decadentes. Meyrink se basa en la famosa leyenda del rabino Loew y el ser artificial (creado del barro) Golem, pero su Golem está asociado sobre todo con la idea de lo misterioso y raro. Golem es un hombre extraño, mítico y, además, el doble del protagonista Pernath, el reflejo de su alma. Pernath se

\footnotetext{
${ }^{17}$ En el s. XVI el alquimista de la corte de Rodolfo II. (y posiblemenete espía de la reina inglesa Isabel I) Edward Kelley.

${ }^{18}$ Recordemos la obra Angelo Maria Ripellino Praga Mágica (1973).

${ }^{19}$ Jorge Luis Borges le dedica un texto en sus Textos cautivos.
} 
disfraza de Golem para llegar a la conclusión de que él es ese ser raro. La atmosféra del misterio es reforzada por el escenario del ghetto. ${ }^{20}$

Praga fue el espacio vital y el escenario de sus obras también para Jiř́i Karásek ze Lvovic. En 1900 publica la novela Gotická duše (El alma gótica). En el prólogo caracteriza su estética, su visión del arte y de la realidad; afirma que no se trata de una novela clásica, sino de una suma de impresiones y estados psíquicos; el protagonista vive "fuera de la realidad circundante; [...] Es indiferente a los dolores que la vida real pueda originar. El verdadero dolor reside en su alma y mientras parece como si no sintiera los dolores reales, los dolores ficticios le atormentan cada vez más..." (Karásek, 1991: 9). El protagonista ("el último descendiente de una antigua familia noble, de la que sobrevivían varias mujeres que sufrían de histeria, mientras que otros miembros de la familia terminaron enloqueciendo"; Karásek, 1991: 13) es un hombre raro y solitario; pasea por los templos praguenses en busca de Dios, el único ser capaz de salvarlo de su desesperanza y fatiga vital. Ni siquiera le satisface el amor: en vano busca un amigo bello y tierno. No lo encuentra, así que trata de lograr la salvación en su propio interior y en su identidad checa -mira la ciudad praguense desde la colina de Petř́n teniendo visiones fantasmagóricas, viendo la urbe en su gloria medieval (gótica) y dándose cuenta de su decadencia posterior en el Imperio austro-húngaro-. Le queda únicamente su dolor y soledad. "Todo fracasó. Se resignó. No quedaba nada por hacer. En su vida todo había marchitado antes de que pudiera probarlo. Sus jardines quedaron vacíos" (Karásek, 1991:74). Le encuentran enloquecido en un templo y lo llevan a un manicomio donde muere.

Jiří Karásek sigue en esta línea de héroes raros, incapaces de aceptar el mundo circundante, en sus Romány tř́ mágů (Novelas de tres magos), formadas por tres novelas cortas: Román Manfreda Mcmillena (1907, Novela de Manfred Mcmillen), Scarabeus (1908) y Ganymedes (1925). Las tres tratan temas relacionados con lo sobrenatural y lo científico, así como con el amor homosexual.

Novela de Manfred Mcmillan sumerge al lector en el ambiente praguense; el narrador conoce al personaje enigmático y demoníaco, el conde Manfred, quien vino a Praga para buscar huellas del conocido de su abuelo, el mago Cagliostro. Está obsesionado con la idea de que él mismo es una reencarnación del mago. El narrador Francis se siente totalmente hechizado y subyugado por el conde. No obstante, ni este es omnipotente; lo persigue otro hombre misterioso, Walter More, quien, mediante prácticas mágicas, logra capturarlo y Manfred desaparece...

Francis y Manfred son los típicos dandys finiseculares; desdeñan la mayoría de la gente, les atrae lo raro, lo peligroso, como afirma el narrador:

Amo solo a los hombres que tienen en sí algún peligro. Toco con placer su interior como si estuviera jugando con una navaja capaz de herirme. Me encanta balancear al borde de abismos sospechosos y por amigos elijo únicamente a personas en cuyo interior acecha el demonio que puede lanzarse sobre mí. (Karásek, 2012:18)

Manfred cree en la importancia de los niveles ocultos de la realidad; opina que "el conocimiento positivista hace estúpido al hombre, así que ponía todo su empeño en saber todo de la magia medieval y no saber nada de lo que proclama la ciencia moderna" (Karásek, 2012: 19). El alma humana es para él algo eterno y sumamente enigmático, el cuerpo solo la cubre y limita. Por eso trata de escuchar el lenguaje del interior, algo que considera fuera del alcance de lo científico, técnico y racional:

Esperaríamos en vano que la ciencia nos aclarara los enigmas de nuestras existencias. La ciencia nunca nos dirá nada. Lo único que puede decirnos es que somos una máquina de nervios llamada hombre. Es la magia la que puede enseñarnos algo de nuestro misterio. Sus hipótesis explican fácilmente las cosas ante las cuales la ciencia se siente impotente. (Karásek, 2012:62)

En los otros dos textos Karásek trabaja con personajes parecidos: raros, homosexuales, aficionados al ocultismo.

Scarabeus abandona el espacio predilecto de Karásek, Praga, para llevarnos a otra ciudad con un potencial de misterio parecido: Venecia. El joven Gaston se enamora de Oreste quien, a la vez, vive una relación turbulenta con el cínico y cruel Marcelo. Cuando Oreste desaparece, Gaston se lanza en su búsqueda descubriendo el secreto del palacio de Marcelo: hay un sarcófago donde yace una pariente de Marcelo, asesina que se deleitaba en envenenar, propietaria de un anillo en forma de escarabeo que contenía un veneno 
poderoso. Marcelo sigue con esta "tradición familiar", envenena a sus amantes, incluido Oreste. Al final Gaston también fallece.

Karásek juega con la veracidad de esta historia terrible. En el último capítulo habla de "mera fantasía" (Karásek, 2012: 351) y afirma que lo "soñó un joven de viente años, cansado de una realidad demasiado vacía" (Karásek, 2012: 351).

Ganymedes recrea el tema de Golem. Adrian Morris se interesa por los misterios de la Praga de Rodolfo II y conoce al escultor Jörn Moller que trata de hacer revivir con ayuda de la cábala a Golem (de modelo para la estatua le sirve el joven Radovan, enamorado de Adrian) - este golem debe cumplir un papel bien diferente de la figura legendaria-: el escultor quiere conseguir así un amigo perfecto, alguien con quien compartir lo más íntimo de su vida. Cuando Moller está a punto de morir, le pide a Adrian que destruya la estatua para siempre. Adrian por casualidad hace lo contrario: Golem despierta y se lo lleva como el águila al mítico Ganymedes.

Los tres protagonistas -Manfred, Marcel y Adrian- son magos. Magos en el mundo moderno que adora el conociminento racional. Se mueven en el espacio de una ciudad moderna, pero a la vez misteriosa y anclada en el pasado (Praga, Venecia), sobre todo por sus iglesias, conventos, jardines y, por supuesto, sus viviendas extrañas, seduciendo a hombres jóvenes, enseñándoles otro tipo de conocimiento, otro tipo de realidad. Para explicar su relación con lo mágico lo racional no basta y así hay elementos que quedan sin resolver. El narrador, además, juega con el nivel de la veracidad añadiendo datos exactos y dudando de la fiabilidad del narrador -igual que en los textos modernistas-. Los artistas finiseculares aprovechan incluso algunos procedimientos de la novela gótica, combinándolos con el decadentismo de la época; según L. Řezníková podemos hablar "de la novela gótica modernista", en la que "la historia ocurre en la actualidad del autor y con el pasado la vinculan solo algunas referencias parciales” (Řezníková, 2006:79).

Resumiendo, los límites de la ciencia y los riesgos con ello unidos, así como la cuestión del conocimiento humano, se nos muestran como temas esenciales del modernismo hispanoamericano, así como del fin de siglo checo. Lo misterioso, fantástico, maravilloso... son sólo términos para distintas facetas de un sentimiento común: que el enfoque racional no siempre basta, que la razón debe ser usada con humildad y consciencia clara de sus limitaciones. Como dice uno de los perosnajes de Karásek:

Y como el destino deja tras sí en el azul [sic] la sombra de nuestras tristezas, renovaremos con doble fuerza misteriosa todas las palabras, ideas de las ciencias mágicas que guardaron en libros olvidados los que vivían y reflexionaban en la Edad Media y morían del cansancio de los viajes que les llevaban a lo más profundo, al centro mismo del Enigma. (Karásek, 2012: 39)

Enigma - de la vida, del amor, del arte...la existencia humana como enigma-. Así es la cosmovisión finisecular. Y lo extraño y misterioso es uno de los impulsos claves del arte de la época. ¿Quién lo podría expresar mejor que Darío?:

“El Enigma es el soplo que hace cantar la lira...” (Darío 1975: 575)

\section{Referencias bibliográficas}

Acereda, Alberto (1992). Rubén Darío, poeta trágico (una nueva visión). Barcelona: Editorial Teide.

Acevedo, Ramón Luis (2002). El discurso de la ambigüedad. La narrativa modernista hispanoamericana. San Juan: Ed. Isla Negra.

Borges, Jorge Luis (1976). Discusión. Madrid: Alianza Editorial.

Campra, Rosalba (2001), "Lo fantástico: una isotopía de la transgresión", en David Roas (ed.). Teorías de lo fantástico. Madrid: Arco/Libros, págs. 153-191.

Carilla, Emilio (1968). El cuento fantástico. Buenos Aires: Ed. Nova

Darío, Rubén (2011). Cuentos completos. Buenos Aires: Losada.

-----, ----- (1920). Los raros. Madrid: Mundo Latino.

-----, ----- (1950-1953). Obras completas. Madrid: Afrodisio Aguado.

------, ------ (1975). Poesías completas. Madrid: Aguilar.

Dražd’ák, K.P. (1995), “Okultismus”, Moderní revue. S., págs., 295-296.

González, Aníbal (1983). La crónica modernista hispanoamericana. Madrid: Ediciones José Porrúa Turanzas.

Hahn, Oscar (1982). El cuento fantástico hispanoamericano en el s. XIX. Mexiko: La red de Jonás, Premia Editora.

Jrade, Cathy (1986). Rubén Dario y la búsqueda romántica de la unidad. El recurso modernista a la tradición esotérica. México: Fondo de Cultura Económica.

Karásek ze Lvovic, Jiří (1991). Gotická duše a jiné prózy. Praha: Vyšehrad. 
(2012). Romány tři mágů. Praha: Volvox Globator.

Martí, José (2013), "Prólogo al Poema del Niágara", en Luis Rafael y Ángel Esteban (eds.). Claves del pensamiento martiano. Ensayos políticos, sociales y literarios. Madrid: Verbum.

Morillas Ventura, Enriqueta (1999), "Los fantasmas rioplatenses de fines del s. XIX”, en Jaume Pont (ed.). Brujas, demonios y fantasmas en la literatura fantástica hispánica. Lleida: Ediciones Universitad de Lleida, págs. 269-277.

Onís, Federico de (1961). Antología de la poesía española e hispanoamericana. New York: Las Américas.

Paz, Octavio (1969), "El caracol y la sirena”, en Cuadrivio. México: Ed. Joaquín Mortiz.

----, ------- (1999). Los hijos del limo, en La casa de la presencia. Poesía e histora. Barcelona: Galaxia Gutenberg.

Procházka, Arnošt (1896), "K poslední fasi české poezie”, en Almanach secese. Praha: S. K. Neumann.

------- (1913). Polemiky literární a umělecké. Praha: Kamila Naumannová.

Ripellino, Angelo Maria (2009). Magická Praha. Praha: Argo.

Roas, David (2001). Teorías de lo fantástico. Madrid: Arco/Libros.

Roetker, Susana (2005). La invención de la crónica. México: Fondo de Cultura Económica.

Řezníková, Lenka (2006), "Gotická duše moderny. Gotika a gotický román v české literatuře přelomu 19. a 20. století”, en Dagmar Blümlová y Bohumil Jiroušek (eds.). Čas moderny: studie a materiály. České Budějovice: Jihočeská univerzita v Českých Budějovicích, Filozofická fakulta.

Sáinz de Medrano, Luis (1991), “Cien años de literatura fantástica”, en Enriqueta Morillas Ventura (ed.). El relato fantástico en España e Hispanoamérica. Madrid: Siruela, págs. 17-26. 